\title{
Study of the Influence of Ultrasound in the Process of Osmotic Drying of Melon
}

\section{Radjabov Mansur Farkhodovich*, Kurambaev Sherzod Raimberganovich, Saparov Makhmud Kadamovich, Khakimova Bakhor Bakhtiyarovna, Rakhmanova Mukhabbat Ismailovna and Abdullaeva Gulnoza Ulugbek Qizi}

Department of Food Technology, Faculty of Chemical Technology, Urgench State University, Urgench, Khorezm, Uzbekistan

*Corresponding Author: Radjabov Mansur Farkhodovich, Department of Food Technology, Faculty of Chemical Technology, Urgench State University, Urgench, Khorezm, Uzbekistan.

\section{Annotation}

The article examines the effect of ultrasound and identifies the main factors influencing the osmotic drying of melon pulp.

\section{Abstract}

Due to the deterioration of the ecological and social situation the creation of production technologies is of particular importance canned products providing maximum preservation of native biologically active substances of raw materials, and also using biological processes. It is necessary develop technologies for the production of functional products, where additives are biologically active substances, derived from various parts of fruits and vegetables. At present, there is an awareness of the importance of changing the structure of nutrition, and the demand for products with preventive and medicinal properties is increasing. Vegetables and fruits contain natural antioxidants, vitamins, biologically active and mineral substances, i.e. are one of the raw materials for this kind of products.

Keywords: Ultrasound; Melon; Osmotic Drying; Pulp; Thickness; Concentration

\section{Introduction}

One of the main promising methods is the process of drying fruit crops by combined methods. The prospects of the method are due to the provision of a low-temperature drying regime, obtaining further enriched prophylactic products, improving the quality indicators and the yield of dried products, due to sonication in a syrup solution.

We have investigated the influence of ultrasound and various factors on the kinetics of melon drying and the adsorption of dry substances in the pulp.

\section{Results and Discussion}

Melons of various varieties were used to study the drying process. For example, GOST (interstate standard) 7178-85 with an initial humidity of $86 \%$. At the same time, to study the influence of various factors on the quality and yield of the product for the experiment, melons of the same variety are taken, cut with different thicknesses, weighing up to $1500 \mathrm{~g}$ and with a certain moisture content. Three test portions of the prepared batch are weighed on VLR-500 scales with an accuracy of $0.01 \mathrm{~g}, 500 \mathrm{~g}$ each. One test sample, without processing, is dried in the selected set mode. Another weighed portion, after keeping in syrup for a specified time with different sugar concentrations at a specified temperature, is dried. When kept in syrup every 30 minutes. a sample of the syrup and the product is taken to determine the dry matter in them. The concentration in the syrup was measured by methods according to GOST 6687.2-90, and in the product according to GOST 8756.1387. After processing the melon in syrup, in order for the excess 
syrup to flow out, you need a sample for 20 - 30 minutes. put on rest and then dry.

The experiment was carried out using an ultrasonic apparatus "Ultrasonic cleaner DSA 50-JY" with an oscillation frequency of 40 $\mathrm{KHz}$ and the main parameters influencing the kinetics of the melon pulp drying process are: syrup concentration ac, melon pulp thickness $\delta$.

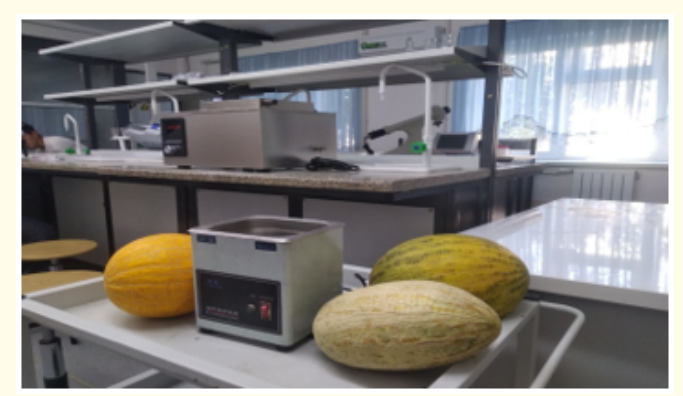

Figure a

The studies were carried out in the following range of process parameters.

$a_{c}$ - syrup concentration from 50 to $70 \%$;

$\delta$ - product thickness from 10 to $30 \mathrm{~mm}$.

As a result of the experiment, the curves of the adsorption kinetics of melon in sugar syrup were obtained depending on the concentration of the syrup, on the thickness of the melon pulp (Figure 1).

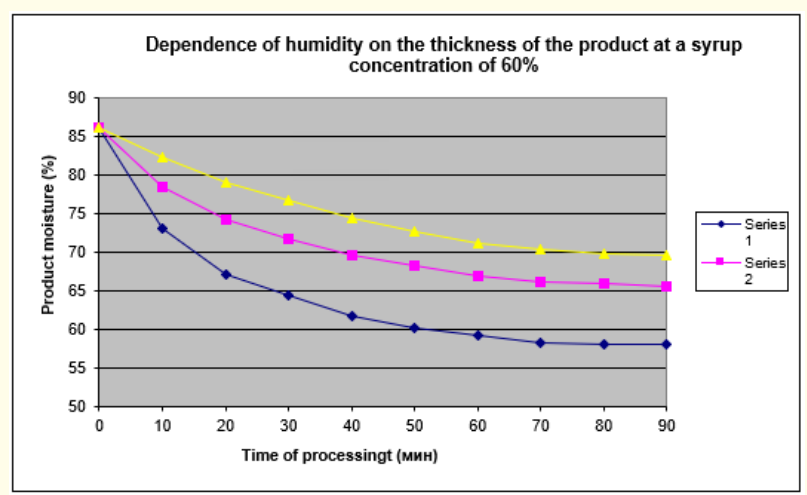

Figure 1

Where: 1 row, pulp thickness is $10 \mathrm{~mm}$; 2 row pulp thickness 20 $\mathrm{mm} ; 3$ pulp thickness $30 \mathrm{~mm}$.

Comparison tables for the experimental data on the moisture content of processed and non-treated samples with ultrasound [1] were obtained, depending on the thickness of the product and the concentration of the syrup.

Experimental data were obtained on the yield of the finished product (the amount of dry substances was determined according to GOST (interstate standard) 8756.13-87.

\begin{tabular}{|l|c|c|c|c|c|c|}
\hline $\begin{array}{l}\text { Concentration of } \\
\text { sugar syrup }\end{array}$ & \multicolumn{2}{|c|}{$\mathbf{5 0 \%}$} & \multicolumn{2}{c|}{$\mathbf{6 0 \%}$} & \multicolumn{2}{c|}{} \\
\hline Sample thickness & $\begin{array}{c}\text { Conventional } \\
\text { processing }\end{array}$ & $\begin{array}{l}\text { Ultrasonic } \\
\text { treatment }\end{array}$ & $\begin{array}{c}\text { Conventional } \\
\text { processing }\end{array}$ & $\begin{array}{l}\text { Ultrasonic } \\
\text { treatment }\end{array}$ & $\begin{array}{c}\text { Conventional } \\
\text { processing }\end{array}$ & $\begin{array}{c}\text { Ultrasonic } \\
\text { treatment }\end{array}$ \\
\hline $1 \mathrm{sm}$ & 68 & 62 & 64 & 58 & 60 & 54 \\
\hline $2 \mathrm{sm}$ & 69 & 67 & 68 & 65.5 & 67 & 64.5 \\
\hline $3 \mathrm{sm}$ & 72 & 70 & 71,4 & 69,5 & 70 & 68 \\
\hline
\end{tabular}

Table 1

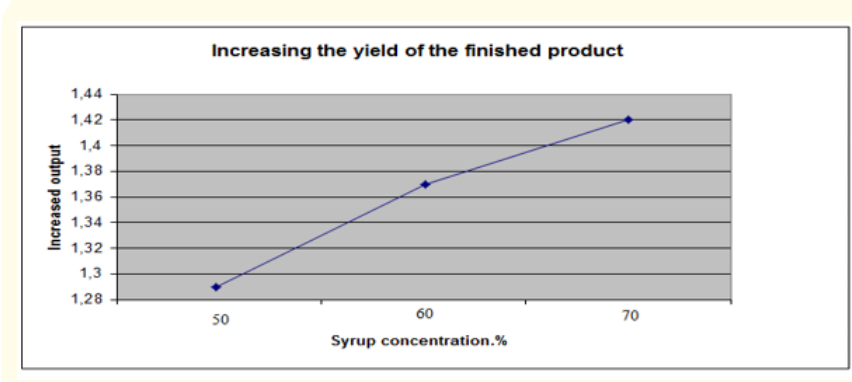

Figure 2

Taking into account the post-processing parameters such as the sugaring of the $10 \mathrm{~mm}$ sample and the post-processing drying time, we assume the optimal drying of the melon pulp with a thickness of $20 \mathrm{~mm}$ at a sugar syrup concentration of $60 \%$. The formula for the dependence of product moisture on the processing time was obtained by interpolation.

$y=84,35-0.5301 x+0,0037 x^{2}$

\section{Conclusion}

As a result of research and analysis of the available data, it was revealed that, in comparison with the usual effect of dense layers 
(for example, sugar syrup) on the pulp of biological raw materials, a combination with ultrasonic exposure is more effective. The main factors influencing the osmotic drying of melon pulp have been identified. An equation for the dependence of the moisture content of the product on the processing time is obtained by the interpolation method [2].

\section{Bibliography}

1. Radjabov MF and Safarov OF. "Research on the osmotic drying process of melon". Chemistry and chemical technology - Tashkent 2.24 (2009): 72-74.

2. Johnson N and Lyon F. "Statistics and planning of experiments in technology and science". Mir (1981): 145-160.

\section{Assets from publication with us}

- Prompt Acknowledgement after receiving the article

- Thorough Double blinded peer review

- Rapid Publication

- Issue of Publication Certificate

- High visibility of your Published work

Website: www.actascientific.com/

Submit Article: www.actascientific.com/submission.php

Email us: editor@actascientific.com

Contact us: +919182824667 